\title{
THE RELATION BETWEEN SELF-DISCLOSURE OF STUDENTS TO THEIR PARENTS AND MATHEMATICS SCORE IN COMPUTER-BASED NATIONAL EXAM (UNBK)
}

\author{
Moch Abduh ${ }^{1}$, Bagus Hary Prakoso ${ }^{1}$, Dian Rahdiani ${ }^{1}$ and Jaka Warsihna ${ }^{2}$ \\ ${ }^{I}$ Centre for Educational Assessment, Ministry of Education and Culture \\ Jl. Gunung Sahari Raya No. 4, Jakarta, 10710, Indonesia \\ ${ }^{2}$ Institute of Research and Community Service (LPPM), Indonesia Open University \\ $\mathrm{Jl}$. Cabe Raya Tangerang Selatan, 15418, Indonesia
}

\begin{abstract}
One of non-cognitive factors which has not been optimally explored in supporting academic achievement was self-disclosure. To overcome that problem, the purpose of this study is to examine the relation between students' self-disclosure to their parents and the mathematics score achievement in the Computer-Based National Exam (UNBK) program. This study used descriptive analysis and correlation analysis as a research method. The study used the mathematics score of Junior High School (SMP) and Islamic Junior High School (MTs) students in 2018 UNBK in DKI Jakarta and DI Yogyakarta provinces as samples. The study shows that (1) there is a positive relation between students' self-disclosure to their parents and mathematics score achievement, and (2) students with low self-disclosure had a greater risk of achieving mathematics scores in the low category. The findings of this study are expected to extend the contribution of self-disclosure in enhancing academic achievement, and the development of a self-disclosure instrument for UNBK questionnaire.
\end{abstract}

\section{KEYWORDS}

Self-Disclosure, Mathematics Scores, Computer-Based National Exam

\section{INTRODUCTION}

The National Exam (UN) is an activity to measure graduates 'competency achievement in certain subjects nationally by referring to Graduates' Competency Standards (SKL). The activities of learning outcomes assessment in education units are carried out by the Ministry of Education and Culture (Kemdikbud) of the Republic of Indonesia every year (Kemdikbud Regulation no. 4 year of 2018).

Since the 2015 school year, the implementation of the National Exam (UN) has applied the Computer Based Test (CBT) mode. In Indonesia program, it is known as the Computer-Based National Examination (UNBK). The implementation of UNBK as a substitute for Paper-Based National Exam (UNKP) which aim to improve efficiency (Sudiyarto, 2018), be more educated and challenging (Belloti, et al (2013), improve the quality of exam (Nizam, 2018), and be more efficient, transparent and has the ability to minimize fraud in cognitive evaluation (Nugroho, et al. 2018).

Indonesia is the largest archipelago with more than 13 thousand islands, has approximately 8.3 million students of secondary school students (formal and non-formal). As of March 11, 2019, the use of UNBK mode has reached 90.0\% (http://un.kemdikbud. go.id). In UNBK for Junior High School (SMP) and Islamic Junior High School (MTs), there are 4 subjects tested, namely: Indonesian, English, Science, and Mathematics. The National Exam Results Report 2015-2019 stated that the achievement of mathematics average score is always at the lowest level compared with three other subjects, both for junior and senior high school levels (https://puspendik.kemdikbud.go.id/hasil-un/). This is very exciting and to be the reason for the study linking to the UNBK questionnaire containing self-disclosure items. 
The contents of the 2017/2018 UNBK questionnaire seemed to reflect the definition of self-disclosure as verbal communication in private information, individual concepts and emotions conducted by individuals for making the other party understood (Wei et al. 2005). Furthermore, how the non-cognitive questionnaire (self-disclosure) in UNBK becomes pivotal instrument to support academic achievement as Garcia (2014) stated. To explore among mathematics score, questionnaire result, and self-disclosure concepts, furthermore the research findings are included.

The research findings outside Indonesia by Harper, V. B., \& Harper, E. J. (2006) connecting with the role of blogging stated that student self-disclosure plays an important role in learning and producing positive learning outcomes. This study provided an indication that blogging encouragement was student self-disclosure. Other research on self-disclosure contribution stated that many authors suggest that self-disclosure plays a critical role in student participation (Goldstein \& Benassi, 1994), facilitating student teacher interaction (Fusani, 1994), and achieving learning objectives (Cayanus, 2004 ; Downs, Javidi, \& Nussbaum, 1988; Sorenson, 1989).

The research finding in Indonesia connecting to the UNBK mathematics scores by Azis and Sugiman (2015) stated that the cognitive aspects consisting of factual, conceptual, and procedural knowledge have generated indications of varied categories (low, medium, and high). On the affective aspects (personal students in social interaction, manners and respect for teachers) to face the national exam were generally in the low category.

The concept and characteristic of self-disclosure are very varied. According to Devito (2011) in self-disclosure there were five dimensions such as: amount, valence self-disclosure, accuracy/honesty, intention, and intimacy. The type of dimension consists of 6 indicators, namely: attitudes and opinions, tastes and interests, school, finance, personality, and physical (Jourard, 1971). In Indonesia educational practice, the age of junior high school students can be categorized as teenagers with the age range of 12 years to 15 years (Monks \& Knoer, 2006). At this period, the child within the developmental period is looking for an identity. They need mentoring parents as a place to share feelings and exchange ideas. Williams \& Burden (1997) used a term "mediator" for parent role that will affect children's cognitive development.

Regarding those concepts, research results, and to increase the mathematics score in UNBK, it is necessary to explore and strengthen the concept of self-disclosure through the UNBK questionnaire by verifying and comparing the cases. Based on the background of the problems, the purpose of this study is to examine the relation between self-disclosure of students towards their parents and mathematics scores at UNBK program. The results of this study are expected to be fruitful for policy recommendations about the importance of the self-disclosure role as supporting academic achievement in non-cognitive aspect.

\section{RESEARCH METHOD}

This study uses description analysis and correlation analysis supported by survey methods, where only a portion of the selected population units is observed (samples), and the unit selection procedure follows scientific method and procedures (Safari, 2018). Questionnaires have been used to reveal and measure the variables of student self-disclosure to parents. The questionnaires were completed on the last day of the UNBK implementation and were filled directly using a computer.

\subsection{Population and Sample}

The population of this study was the $9^{\text {th }}$ grade junior high school (SMP) students who undertook in the 2018 UNBK in the province (DKI Jakarta and DI Yogyakarta) that has implemented a $100 \%$ UNBK program. The UNBK implementation is carried out in its own school or through facility sharing programs (see Figure 1, Figure 2, and Table 1).

Not all the UN participant students can access and fill out the UN questionnaire. Only students who attend UNBK can fill in the questionnaire. Sample determination with Slovin technique (Sugiono, 2011) consisted of representatives of 20 students in each the UNBK participating school. Here is the Slovin formula to determine the sample. 


$$
\mathbf{n}=\frac{N}{1+N(e)^{2}}
$$

Note:

$\mathrm{n}=$ number of sample / respondent; $\mathrm{N}=$ number of population

$\mathrm{E}=$ percentage of accuracy on sampling errors that can still be tolerated; $\mathrm{e}=0,1$

In the Slovin formula there are provisions as follows: the value of e $=0.1(10 \%)$ for the population in large numbers and the value of $\mathrm{e}=0.2(20 \%)$ for the population in small numbers. The sample range that can be taken from Slovin techniques is between $10-20 \%$ of the study population. Based on data from UNBK 2017 there were 3.6559 .696 students. If using the Slovin formula obtained value $\mathrm{n}=$ Population: $(\mathrm{N})=3.6559 .696$ people assuming the error rate $(\mathrm{e})=10 \%$ then the number of samples $(\mathrm{n})$ is $\mathrm{n}=99.99=100$.

The data of participant schools in 2017 UNBK was 11.096. If the sample from each school is 20 questionnaires, then the questionnaire data that will be collected is $20 \times 11.096=220,192$ questionnaires. If all of this data is analyzed, it will be a big sample.

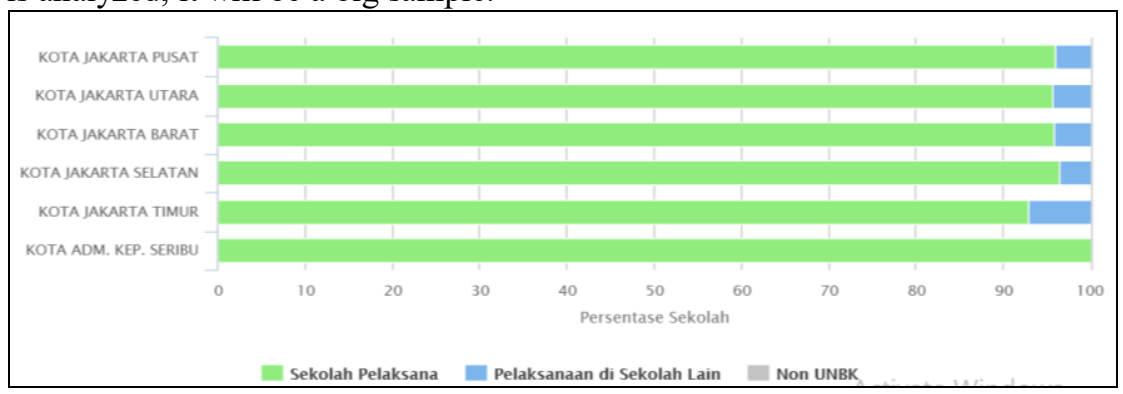

Figure 1. School Percentage in DKI Jakarta that carry outs UNBK

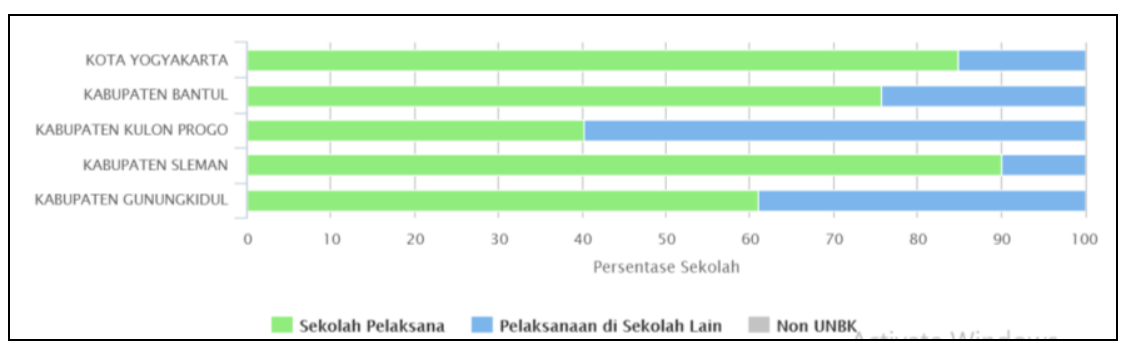

Figure 2. School Percentage in DI Yogyakarta that carry outs UNBK

Table 1. Respondent

\begin{tabular}{|c|c|}
\hline Province & Number of Respondent \\
\hline DKI Jakarta & 10.996 \\
\hline DI Yogyakarta & 5.854 \\
\hline
\end{tabular}

\subsection{Score Category}

Table 2. Mathematics Score in UNBK

\begin{tabular}{|l|c|c|c|c|}
\hline \multirow{2}{*}{ Score Category } & \multicolumn{2}{|c|}{ DKI Jakarta } & \multicolumn{2}{c|}{ DI Yogyakarta } \\
\cline { 2 - 5 } & Number of Student & $\%$ & Number of Student & $\%$ \\
\hline Less $=0.0-55$ & 7009 & $63.8 \%$ & 3061 & $52.4 \%$ \\
\hline Enough $=55.1-70$ & 1499 & $13.6 \%$ & 1035 & $17.7 \%$ \\
\hline Good $=70.1-85$ & 1331 & $\mathbf{1 2 . 1 \%}$ & 852 & $\mathbf{1 4 . 6 \%}$ \\
\hline Very Good $=85.1-100$ & 1157 & $\mathbf{1 0 . 5 \%}$ & 897 & $\mathbf{1 5 . 3 \%}$ \\
\hline Total & 10996 & $100 \%$ & 5845 & $100 \%$ \\
\hline
\end{tabular}




\subsection{Research Instrument}

This study uses instruments applied in the 2017/2018 UNBK questionnaire. The variables used were questions related to students' self-disclosure to their parents, namely:

Table 3. Self-Disclosure Instrument

\begin{tabular}{|c|c|c|c|c|c|c|}
\hline $8 \mathrm{a}$ & \multirow{5}{*}{$\begin{array}{l}\text { How often have } \\
\text { you done the } \\
\text { following things } \\
\text { with your } \\
\text { parents? }\end{array}$} & Tell activities with your friends & Always & Often & Rarely & Never \\
\hline $8 \mathrm{~b}$ & & Discuss lessons at school & Always & Often & Rarely & Never \\
\hline $8 \mathrm{c}$ & & Discuss the tasks from the teacher & Always & Often & Rarely & Never \\
\hline $8 \mathrm{~d}$ & & Tells stories about events at school & Always & Often & Rarely & Never \\
\hline $8 \mathrm{e}$ & & Discuss about the personal things you feel & Always & Often & Rarely & Never \\
\hline
\end{tabular}

\section{RESULT AND DISCUSSION}

\subsection{Frequency of Student Response Patterns}

Based on table 4 and table 5 can be obtained the most prominent of self-disclosure activities data, namely: (1) telling activities with friends showed that the smallest percentage of never answers (5.2\% for DKI Jakarta students, and 3.5\% for DI Yogyakarta students), (2) discussion of lessons in schools shows that the largest percentage of rare answers $(43.8 \%$ for DKI Jakarta students and $43.6 \%$ for DI Yogyakarta students), (3) discuss the tasks from the teacher indicate that the largest percentage of rare answers $(49 \%$ for DKI Jakarta students and 51.8\% for DI Yogyakarta students), (4) telling stories about events in schools show that the largest percentage of often answers $(40.9 \%$ for DKI Jakarta students and $43.1 \%$ for DI Yogyakarta students), (5) discussion activities about something personal shows that the smallest percentage of rare answer (41\% for DKI Jakarta never and 45,6\% for DI Yogyakarta students), and (6) in general, the comparative tables show that both SMP/MTs students in DKI Jakarta and DI Yogyakarta have similar pattern in determining the answers.

Table 4. The frequency table of students' self-disclosure to parents in DKI Jakarta

\begin{tabular}{|c|c|c|c|c|c|c|c|c|c|c|c|c|}
\hline $\begin{array}{c}\text { Instru- } \\
\text { ment }\end{array}$ & \multicolumn{2}{|c|}{$\begin{array}{c}\text { Tell activities } \\
\text { with your friends }\end{array}$} & \multicolumn{2}{c|}{$\begin{array}{c}\text { Discuss lessons at } \\
\text { school }\end{array}$} & \multicolumn{2}{c|}{$\begin{array}{c}\text { Discuss the tasks } \\
\text { from the teacher }\end{array}$} & \multicolumn{2}{c|}{$\begin{array}{c}\text { Tells stories about } \\
\text { events at school }\end{array}$} & $\begin{array}{c}\text { Discuss about the } \\
\text { personal things }\end{array}$ \\
\hline Answer & Respondent & $\%$ & Respondent & $\%$ & Respondent & $\%$ & \multicolumn{2}{c|}{ Respondent } & \multicolumn{1}{c|}{$\%$} & Respondent & $\%$ \\
\hline \multicolumn{8}{|c|}{ DKI Jakarta Province } \\
\hline Never & 569 & $\mathbf{5 . 2}$ & 658 & 6 & 1093 & 9.9 & 631 & 5.7 & 1755 & $\mathbf{1 6}$ \\
\hline Rarely & 4085 & 37.1 & 4813 & $\mathbf{4 3 . 8}$ & 5384 & $\mathbf{4 9}$ & 3531 & 32.1 & 4509 & 41 \\
\hline Often & 4116 & 37.5 & 3969 & 36 & 3381 & 30.8 & 4492 & $\mathbf{4 0 . 9}$ & 2884 & $\mathbf{2 6 . 2}$ \\
\hline Always & 2226 & 20.2 & 1556 & 14.2 & 1138 & 10.3 & 2342 & $\mathbf{2 1 . 3}$ & 1848 & $\mathbf{1 6 . 8}$ \\
\hline Total & 10996 & 100 & 10996 & 100 & 10996 & 100 & 10996 & 100 & 10996 & 100 \\
\hline
\end{tabular}

Table 5. The frequency table of students' self-disclosure to their in DI Yogyakarta

\begin{tabular}{|c|c|c|c|c|c|c|c|c|c|c|}
\hline \multirow{2}{*}{$\begin{array}{c}\begin{array}{c}\text { Instru- } \\
\text { ment }\end{array} \\
\text { Answer }\end{array}$} & \multicolumn{2}{|c|}{$\begin{array}{l}\text { Tell activities with } \\
\text { your friends }\end{array}$} & \multicolumn{2}{|c|}{$\begin{array}{c}\text { Discuss lessons at } \\
\text { school }\end{array}$} & \multicolumn{2}{|c|}{$\begin{array}{l}\text { Discuss the tasks } \\
\text { from the teacher }\end{array}$} & \multicolumn{2}{|c|}{$\begin{array}{c}\text { Tells stories about } \\
\text { events at school }\end{array}$} & \multicolumn{2}{|c|}{$\begin{array}{l}\text { Discuss about the } \\
\text { personal things }\end{array}$} \\
\hline & Respondent & $\%$ & Respondent & $\%$ & Respondent & $\%$ & Respondent & $\%$ & Respondent & $\%$ \\
\hline Never & 205 & 3.5 & 275 & 4.7 & 464 & 7.9 & 237 & 4.1 & 630 & 10.8 \\
\hline Rarely & 2247 & 38.5 & 2550 & 43.6 & 3023 & 51.8 & 2099 & 35.9 & 2667 & 45.6 \\
\hline Total & 5845 & 100 & 5845 & 100 & 5845 & 100 & 5845 & 100 & 5845 & 100 \\
\hline
\end{tabular}




\subsection{Self Disclosure Index}

In this study, the self disclosure index is categorized into three categories: high, medium, and low level. In general, the activities of students' self-disclosure to their parents are in the medium category (around $74 \%$ for DKI Jakarta SMP/MTS students and around 64.2\% for DI Yogyakarta SMP/MTs students).

It is shown that $15.7 \%$ of SMP/MTs students in DKI Jakarta and $16.2 \%$ of SMP/MTs students in DI Yogyakarta belong to the high category. In the low category, there are $10.3 \%$ for SMP/MTS students in DKI Jakarta and 19.7\% for SMP/MTs students in DI Yogyakarta. Furthermore, the activities of self-disclosure of SMP/MTs students in DKI Jakarta and DI Yogyakarta towards their parents are fairly transparent generally.

\subsection{Correlation Test}

Correlation test is applied to examine of how the relation between student self disclosure to parents and the mathematics score achievement in DKI Jakarta and DI Yogyakarta Provinces, by using hypothesis:

$\mathrm{H} 0=$ There is no relation between student self disclosure to parents and mathematics score achievement.

$\mathrm{H} 1=$ There is relation between student self disclosure to parents and mathematics score achievement.

Criteria: $\mathrm{H} 0$ is rejected if the p-value $<\alpha(5 \%)$.

The analysis results show that between students' self-disclosure to parents and the mathematics score in Yogyakarta has a significant score of 0.000 , whereas for DKI Jakarta has a significant score of 0.007 . Both provinces have a significant score of $<0.05$, which means that there is a significant correlation between students' self-disclosure to their parents and the mathematics scores both in DKI Jakarta and in Yogyakarta. The score of the Pearson coefficient correlation is 0.026 for DKI Jakarta and 0.132 for DI Yogyakarta. These results indicate that the high self-disclosure of students to their parents have a positive impact on the mathematics score achievement (see Table 6).

Table 6. Correlation score of between student'self-disclosure to parents and mathematics score

\begin{tabular}{|c|c|c|}
\hline & DKI Jakarta & DI Yogyakarta \\
\hline Correlation & $.026(* *)$ & $.132(* *)$ \\
\hline Sig. (2-tailed) & .007 & .000 \\
\hline \multirow{2}{*}{ Correlation is significant at the 0.01 level (2-tailed). }
\end{tabular}

\subsection{Odds Ratio Test}

Table 7. Odds Ratio Index Category on Self Disclosure and Mathematics Score

\begin{tabular}{|c|c|c|c|c|c|c|c|c|c|}
\hline \multirow{2}{*}{\multicolumn{2}{|c|}{$\begin{array}{l}\text { Mathematics Score } \\
\text { Category }\end{array}$}} & \multicolumn{3}{|c|}{$\begin{array}{c}\text { Category Index of Self Disclosure } \\
\text { for DKI Jakarta }\end{array}$} & \multirow[t]{2}{*}{ Total } & \multicolumn{3}{|c|}{$\begin{array}{c}\text { Category Index of Self } \\
\text { Disclosure for DI Yogyakarta }\end{array}$} & \multirow[t]{2}{*}{ Total } \\
\hline & & Low & Medium & High & & Low & Medium & High & \\
\hline \multirow{2}{*}{$\begin{array}{l}\text { Less }= \\
0-55\end{array}$} & Total & 750 & 5206 & 1053 & 7009 & 726 & 1930 & 405 & 3061 \\
\hline & $\%$ & $66.3 \%$ & $64.0 \%$ & $60.9 \%$ & $63.7 \%$ & $63.1 \%$ & $51.5 \%$ & $42.9 \%$ & $52.4 \%$ \\
\hline \multirow{2}{*}{$\begin{array}{l}\text { Enough }= \\
55.1-70\end{array}$} & Total & 132 & 1116 & 251 & 1499 & 171 & 672 & 192 & 1035 \\
\hline & $\%$ & $11.7 \%$ & $13.7 \%$ & $14.5 \%$ & $13.6 \%$ & $14.9 \%$ & $17.9 \%$ & $20.3 \%$ & $17.7 \%$ \\
\hline \multirow{2}{*}{$\begin{array}{l}\text { Good }= \\
70.1-85\end{array}$} & Total & 123 & 989 & 219 & 1331 & 131 & 552 & 169 & 852 \\
\hline & $\%$ & $10.9 \%$ & $12.2 \%$ & $12.7 \%$ & $12.1 \%$ & $11.4 \%$ & $14.7 \%$ & $17.9 \%$ & $14.6 \%$ \\
\hline \multirow{2}{*}{$\begin{array}{l}\text { Very Good } \\
=85.1-100\end{array}$} & Total & 126 & 826 & 205 & 1157 & 122 & 596 & 179 & 897 \\
\hline & $\%$ & $11.1 \%$ & $10.2 \%$ & $11.9 \%$ & $10.5 \%$ & $10.6 \%$ & $15.9 \%$ & $18.9 \%$ & $15.3 \%$ \\
\hline \multirow[t]{2}{*}{ TOTAL } & Total & 1131 & 8137 & 1728 & 10996 & 1150 & 3750 & 945 & 5845 \\
\hline & $\%$ & $100.0 \%$ & $100.0 \%$ & $100.0 \%$ & $100.0 \%$ & $100.0 \%$ & $100.0 \%$ & $100.0 \%$ & $100.0 \%$ \\
\hline
\end{tabular}

Table 7 shows that SMP/MTs students in DKI Jakarta with low category index of self-disclosure have the opportunity/risk to obtain mathematics scores in the low category is 6-fold $(66.3 \%$ : $11.1 \%)$ compared to achieve mathematics score in high category. Likewise the SMP/MTs students in DI Yogyakarta with low category index of self-disclosure have the opportunity/risk to achieve mathematics scores in low category is 6-fold compared to achieve mathematics score in high category. Those comparative data indicate that both SMP/MTs students in DKI Jakarta and DI Yogyakarta who have low self-disclosure have a greater risk to achieve mathematics score in low category. 
Table 8. Comparison of UNBK mathematics score in self-disclosure activities

\begin{tabular}{|c|c|c|c|c|c|c|c|}
\hline \multirow{2}{*}{$\begin{array}{l}\text { Self-Disclosure } \\
\text { Statements }\end{array}$} & \multirow[b]{2}{*}{ Answer } & \multicolumn{3}{|c|}{ DKI Jakarta } & \multicolumn{3}{|c|}{ DI Yogyakarta } \\
\hline & & Respondent & $\begin{array}{c}\text { Average } \\
\text { Score }\end{array}$ & $\begin{array}{c}\text { Standard } \\
\text { Deviation }\end{array}$ & Respondent & $\begin{array}{c}\text { Average } \\
\text { Score }\end{array}$ & $\begin{array}{l}\text { Standard } \\
\text { Deviation }\end{array}$ \\
\hline \multirow{5}{*}{$\begin{array}{l}\text { Tell activities with } \\
\text { your friends } \\
\text { (Linying \& } \\
\text { Huichang, 2003) }\end{array}$} & Never & 569 & 42.4692 & 18.90340 & 205 & 50.6585 & 21.38422 \\
\hline & Rarely & 4085 & 49.7693 & 21.36575 & 2247 & 54.5216 & 21.10165 \\
\hline & Often & 4116 & 54.7923 & 22.61838 & 2481 & 60.7537 & 21.82722 \\
\hline & Always & 2226 & 51.3017 & 22.22039 & 912 & 61.1157 & 22.05941 \\
\hline & Total & 10996 & 51.5819 & 22.10880 & 5845 & 58.0603 & 21.82672 \\
\hline \multirow{5}{*}{$\begin{array}{l}\text { Discuss lessons at } \\
\text { school } \\
\text { Dindia and Duck } \\
(2000)\end{array}$} & Never & 658 & 50.7594 & 22.89300 & 275 & 55.3182 & 21.23714 \\
\hline & Rarely & 4813 & 52.6449 & 21.99037 & 2550 & 55.8265 & 21.34206 \\
\hline & Often & 3969 & 51.4766 & 22.29433 & 2342 & 60.3544 & 22.10991 \\
\hline & Always & 1556 & 47.6560 & 21.36035 & 678 & 59.6497 & 21.95354 \\
\hline & Total & 10996 & 51.5819 & 22.10880 & 5845 & 58.0603 & 21.82672 \\
\hline \multirow{5}{*}{$\begin{array}{l}\text { Discuss the tasks } \\
\text { from the teacher } \\
\text { Dindia and Duck } \\
\text { (2000) }\end{array}$} & Never & 1093 & 43.3281 & 22.84748 & 464 & 56.1853 & 22.05667 \\
\hline & Rarely & 5384 & 50.6677 & 21.95500 & 3023 & 57.2891 & 21.62107 \\
\hline & Often & 3381 & 52.9419 & 22.20465 & 1908 & 60.0878 & 21.95247 \\
\hline & Always & 1138 & 52.5758 & 21.35867 & 450 & 56.5778 & 21.87761 \\
\hline & Total & 10996 & 51.5819 & 22.10880 & 5845 & 58.0603 & 21.82672 \\
\hline \multirow{5}{*}{$\begin{array}{l}\text { Tells stories about } \\
\text { events at school } \\
\text { (Linying \& } \\
\text { Huichang, 2003) }\end{array}$} & Never & 631 & 43.3281 & 19.20281 & 237 & 48.5021 & 20.61740 \\
\hline & Rarely & 3531 & 50.6677 & 21.95004 & 2099 & 54.7642 & 21.05924 \\
\hline & Often & 4492 & 52.9419 & 22.33645 & 2523 & 60.4459 & 21.91015 \\
\hline & Always & 2342 & 52.5758 & 22.10676 & 986 & 61.2703 & 21.92923 \\
\hline & Total & 10996 & 51.5819 & 22.10880 & 5845 & 58.0603 & 21.82672 \\
\hline
\end{tabular}

Based on table 8, the analysis results and interpretation are presented as follows: (1) students who always do activities tell stories about events in schools having higher math scores (around 9 points in DKI Jakarta and 13 points in DI Yogyakarta) compared to students who have never done activities to parents, (2) students in DKI Jakarta and DI Yogyakarta who always do activities like discussing personal matters also have higher mathematical values (around 2 points in DKI Jakarta and 5 points in DI Yogyakarta) compared to students who have never done the activity, even though the difference of score is not significant, (3) students in DKI Jakarta who always do activities like discussing the assignments from teachers have higher scores (around 9 points) compared to students who never do these activities, (4) for students in DI Yogyakarta this activity has no impact anything in mathematics score achievement, because students who always discuss the assignments from teachers and students who never do these activities have relatively similar of mathematics scores, (5) activities like discussing lessons in schools actually have a negative impact on mathematics score achievement for DKI Jakarta students. The students who always do activities like discussing lessons in school with their parents have lower mathematics scores (around 3 points) compared to students who never do these activities, (6) for DI Yogyakarta students who always do activities like discussing school lessons with their parents have a greater score (around 4 points) compared students who never do so. Thus, this activity has a negative impact on the mathematics score for DKI Jakarta students, but has a positive impact on mathematics scores for DI Yogyakarta students, and (7) The students who always tell activities with friends have higher mathematics scores (around 9 points for DKI Jakarta and 11 points for DI Yogyakarta compared to students who are rarely or never doing these activities.

Table 9. Comparison of UNBK mathematics score in self-disclosure activities

\begin{tabular}{|l|c|c|c|c|c|c|c|}
\hline \multirow{2}{*}{$\begin{array}{l}\text { Self-Disclosure } \\
\text { Statements }\end{array}$} & Answer & Respondent & $\begin{array}{c}\text { Average } \\
\text { Score of } \\
\text { Math }\end{array}$ & $\begin{array}{c}\text { Standard } \\
\text { Deviation }\end{array}$ & Respondent & $\begin{array}{c}\text { Average } \\
\text { Score of } \\
\text { Math }\end{array}$ & $\begin{array}{c}\text { Standard } \\
\text { Deviation }\end{array}$ \\
\cline { 3 - 8 } $\begin{array}{l}\text { Discuss about the } \\
\text { personal things } \\
\text { (Jourard and Jaffee, }\end{array}$ & Never & 1755 & 47.8718 & 21.38870 & 630 & 53.6786 & 21.43338 \\
\cline { 2 - 8 } $\begin{array}{l}\text { 1970); } \\
\text { (Vogel, D. L. \& } \\
\text { Wester, S. R., 2003) }\end{array}$ & Rarely & 4509 & 53.5207 & 22.43865 & 2667 & 57.7325 & 21.71685 \\
\cline { 2 - 8 } & Often & 2884 & 52.1663 & 22.10833 & 1755 & 59.8362 & 22.03040 \\
\cline { 2 - 8 } & Always & 1848 & 49.4629 & 21.35943 & 793 & 58.7137 & 21.56373 \\
\hline
\end{tabular}


In general, the relation between student self-disclosure and mathematics scores in DI Yogyakarta is slightly higher than that of DKI Jakarta. This presumably occurred because: (1) the number of SMP /MTs students in DKI who participate in UNBK is almost double than that of DI Yogyakarta SMP/MTs students; (2) DI Yogyakarta province often achieves the highest average UNBK score nationally; (3) academic achievements of DI Yogyakarta are in line with the highest achievements of the Good Governance Index (https://kemendagri.go.id/blog/3453-Ini-Hasil-Tata-Kelola-Daerah-Versi-IGI), and the Teacher Competency Test (Jacobson B. N., 2012.), (Umar M. R., 2018), (B.O. Onyilo and I. I. Shamo, 2017), (npd.data. kemdikbud.go.id).

The academic achievements obtained by DI Yogyakarta students hitherto are strengthened by the research finding that in order to improve the UNBK score and education quality in the broadest level, the technical and strategic approaches at each school should be supported by participation among stakeholders and social culture strength (Prakoso, 2018).

\section{CONCLUSION}

The study shows that (1) there is a positive relation between SMP/MTs students' self-disclosure to their parents and UNBK mathematics score for both DKI Jakarta and DI Yogyakarta provinces, (2) students with low self-disclosure have a greater risk of achieving mathematics scores in less category $(<55)$. The both results indicate that non-cognitive factors in the form of family support, especially in terms of communication between students and their parents have a positive impact on academic achievement.

\section{ACKNOWLEDGEMENT}

The authors expresses their utmost gratitudes to the Centre for Educational Assessment (Puspendik) and Puspendik's Management for support and contribution. The second utmost gratitudes are to Dr. Rahmawati for analysis contribution and Haryo Susetyo for UNBK information.

\section{REFERENCES}

Azis and Sugiman, 2015. An Analysis of Difficulty on Cognitive and Problem on Affective of SMA Students in Mathematics Learning Facing National Examination. Jurnal Riset Pendidikan Matematika, Vol. 2 No. 2, November 2015, 162 - 174. Retrieved from http://Journal.Uny.Ac.Id/Index.Php/Jrpm/Index

B.H. Prakoso., 2018. Promoting Best Practices of Computer Based National Exam (UNBK) Achievement in Indonesia. Turkish Online Journal of Educational Technology, Special Issue, Vol.2, 418-425.

B.O. Onyilo and I. I. Shamo, 2017. Teacher Competence as a Tool for Effective and Sustainable Human Capital Development in the Federal Capital Territory: Implications for Career Guidance. International Journal of Psychology and Counselling. Vol. 9(3),17-22.

Belloti, Fransesco, 2013. Advances in Human-Computer Interaction. Journal of Gale Economic Education Humanities Social-Science. Retrieved from http://infotrac.galegroup.com.

Cayanus, J. L., 2004. Using teacher self-disclosure as an Instructional Tool. Communication Teacher. 18, 6-9.

DeVito, J. A., 2011. Communication among People. Karisma Publishing Group. Tangerang, Indonesia.

Dindia, K., \& Duck, S. 2000. Communication and Personal Relationships. Wiley. New York, USA.

Downs, V., Javidi, M., \& Nussbaum, J., 1988. An Analysis of Teachers' Verbal Communication within the College Classroom: Use of humor, self-disclosure, and narratives. Communication Education, 37, 127-141.

Fusani, D. S., 1994. Extra Class Communication: Frequency, Immediacy, Self-Disclosure, and Satisfaction in Student-Faculty Interaction Outside the Classroom. Journal of Applied Communication Research, 22, 232-255.

Goldstein, G. S., \& Benassi, V. A. 1994. The relation between teacher self-disclosure and student classroom participation. Teaching of Psychology, 21, 212-217.

Gutman, L. M., \& Schoon, I., 2013. The Impact of Non-Cognitive Skills on Outcomes for Young People. Education Empowerment Foundations. London, UK. 
Harper, V. B., \& Harper, E. J. 2006. Understanding Student Self-Disclosure Typology through Blogging. The Qualitative Report, 11(2), 251-261. Retrieved from https://nsuworks.nova.edu/tqr/vol11/iss2/3

Jacobson B. N., 2012. Teachers' Competence and Students' Academic Performance in Senior Secondary Schools Chemistry: Is there any Relationship? Global Journal of Educational Research. Vol 11, No. 1, 15-18.

Jourard, S. M. \& Jaffee, P. E., 1970. Influence of an interviewer's disclosure on the self-disclosing behavior of interviewees. Journal of Counseling Psychology, 17, 252-257.

Jourard, S. M., 1971. Self-disclosure: An Experimental Analysis of the Transparent Self. Wiley Inter science. New York, USA.

Linying, L., \& Huichang, C. 2003. Relation between self-disclosure and personality characteristics, loneliness, mental health. Chinese Mental Health Journal, 17(10), 666-671.

Monks, F.J., Knoers, A.M.P., Haditono, S.R., 2006. Psikologi Perkembangan: Pengantar dalam Berbagai Bagiannya. Gadjah Mada University Press. Yogyakarta, Indonesia.

Nizam, 2018. Biaya UNBK dan UNKP Beda Tipis. Retrieved from http://inilampung.com/biaya-unbk-dan-unkp-bedatipis

Nugroho, R.A; N.S Kusumawati; O.C Ambarwati, 2018. Students Perception on the Use of Computer Based Test. IOP Conference Series : Materials Science and Engineering, Volume 306 (2018) 012103.

Safari. 2018. Data Analysis with Computer Program. Universitas Negeri Jakarta. Jakarta, Indonesia.

Sorenson, G., 1989. The relationships among teachers' self-disclosive Statements, Students' Perceptions, and Affective Learning. Communication Education, 38, 259-276.

Sudiyarto, 2018. UNBK Tekan Anggaran Ujian Nasional Hingga 70 \%. Retrieved from https://nasional.tempo.co/ $\mathrm{read} / 1069466 /$ kemendikbud-unbk-tekan-anggaran-ujian-nasional-hingga-70-persen/full\&view=ok

Sugiyono. 2011. Metode Penelitian Kuantitatif, Kualitatif, dan R \& D. Alfabeta. Bandung, Indonesia.

Umar M. R., 2018. Relationship between Teacher Competence, School Climate and Academic Performance of Public Senior Secondary School Students in Sokoto State Nigeria. International Journal of Humanities and Social Science Invention (IJHSSI). Vol. 7(1), 34-40.

Vogel, D. L. \& Wester, S. R., 2003. To seek help or not to seek help: the risks of self-disclosure. Journal of Counseling Psychology, 50(3), pp. 351-361.

Wei, M., Russell, W. D., \& Zakalik, R. A. 2005. Adult attachment, social self-efficacy, self-disclosure, loneliness, and subsequent depression for freshman college students: A longitudinal study. Journal of Counseling Psychology, 52(4), 602-614.

Williams, M. \& Burden, R. L., 1997. Psychology for language teachers: a social constructivist approach. Cambridge University Press. Cambridge, UK.

https://https://www.kemendagri.go.id/blog/3453-Ini-Hasil-Tata-Kelola-Daerah-Versi-IGI

https://npd.data. kemdikbud.go.id

https://puspendik.kemdikbud.go.id/hasil-un/

https://un.kemdikbud.go.id 